\title{
Peningkatan Kecakapan Berkomunikasi dan Hasil Belajar PKn Siswa Kelas 6 dengan Talking Stick Berbantuan Salindia
}

\author{
Hana Septina Kristanti \\ hanaseptina86@gmail.com \\ SD Negeri Dukuh 03, Kec. Sidomukti, Kota Salatiga

\begin{abstract}
Increasing Student's Communication Skills And Learning Results Of Grade 6 In Civics Education With Powerpoint-Assisted Talking Stick Method
\end{abstract}

\begin{abstract}
This study aims to improve communication skills and learning outcomes of Civics in Grade 6 students of SDN Dukuh 03 Salatiga with the application of the Talking Stick assisted $h$ slideshow. This type of research is classroom action research. The location (setting) in this study is grade 6 SDN Dukuh 03 Salatiga. The subjects of the study were 28 students in 6th grade. The object of this research is communication skills and Civics learning outcomes. This research was carried out in 2 cycles. This study was declared successful if the average achievement of indicators of communication skills and classical completeness of student learning outcomes in the good category (60\% -75\%), very good (76\%-99\%), or special $(100 \%)$. The results of the study show that the implementation of the slideshow-assisted Talking Stick in the Civics learning process can improve communication skills and Civics learning outcomes. The communication skills have increased by $23.8 \%$ from pre-cycle to cycle 1 meeting 1. Cycle 1 meeting 2 increased 8.34\% from cycle 1 meeting 1 . Students' communication skills increased from cycle 1 meeting 2 to cycle 2 meeting 1 by $6.75 \%$. Increased again by $7.93 \%$ from cycle 2 meeting 1 to cycle 2 meeting 2. Increased student communication skills proved to be able to improve student learning outcomes in Civics learning. In the pre cycle, only 13 students (46.43\%) were completed, the remaining 15 students (53.57\%) were not completed. In cycle 1 , there were 16 students $(57.14 \%)$ completed, while 12 students (42.86\%) were not completed. After the cycle 2 action was carried out, as many as 22 students (78.57\%) were completed and 6 students (21.43\%) were not completed.
\end{abstract}

Keywords: slideshow in talking stick, communication skills, learning outcomes

Received date: 29 Juni 2018

Article Info

Revised date: 26 Agustus 2018 Accepted date: 21 September 2018

\section{PENDAHULUAN}

Salah satu tujuan pembelajaran Pendidikan Kewarganegaraan (PKn) adalah tercetaknya generasi yang dapat berinteraksi dengan bangsa-bangsa lain dalam percaturan dunia secara langsung dengan memanfaatkan teknologi informasi dan komunikasi. Hal ini sejalan dengan pembelajaran abad 21 di mana kecakapan berkomunikasi atau communication skill merupakan salah satu dari empat kecakapan yang harus dimiliki siswa (Kemdikbud, 2017). Kemampuan ini sangat penting untuk dimiliki siswa, mengingat kehidupan di era global yang semakin kompetitif. Kecakapan berkomunikasi tidak datang dengan sendirinya, kecakapan ini perlu dibiasakan dan dilatih sehingga tercetak generasi yang siap menjawab tantangan zaman. Sehingga menjadi penting bagi guru untuk meramu pembelajaran yang sesuai dengan tujuan tersebut di atas.

Pada mata pelajaran PKn kelas 6 SDN Dukuh 03 Salatiga, guru menerapkan metode tanya jawab untuk merangsang dan melatih kecakapan berkomunikasi siswa. Harapannya, dengan pembelajaran tersebut terjalin komunikasi yang baik antara siswa dengan siswa, siswa dengan guru, dan sebaliknya. Dengan terjalinnya komunikasi yang baik, maka hasil belajar yang dicapai siswa juga akan baik. Namun, fakta saat pembelajaran berlangsung berkata lain. Dari pengamatan guru, metode pembelajaran yang diterapkan kurang efektif untuk melatih kecakapan berkomunikasi siswa. Hanya ada beberapa siswa saja yang merespon positif. Hal ini terlihat dari sedikitnya siswa yang bertanya, menjawab, dan berpendapat. Dari siswa yang bertanya, menjawab, dan berpendapat hanya beberapa 
siswa yang menggunakan tata bahasa yang baik, pembicaraan dan suaranya jelas, melihat lawan bicara, ekspresi wajahnya ramah, dan gerakan tangannya sesuai dengan kata-kata yang diucapkan.

Fenomena lain yang dilihat guru adalah kurang efektifnya media, dalam hal ini buku dalam sesi penggalian materi. Sebagian besar siswa terlihat malas membaca. Nampaknya hal ini yang menyebabkan mereka kurang menguasai materi sehingga hanya sedikit siswa yang merespon positif saat sesi tanya jawab. Rendahnya kecakapan berkomunikasi siswa berbanding lurus dengan hasil belajar siswa. Berikut adalah tabel kecakapan berkomunikasi siswa. Dalam hal ini kecakapan berkomunikasi siswa yang dimaksud adalah aspek komunikasi lisan siswa selama pembelajaran PKn materi Politik Luar Negeri Indonesia berlangsung. Aspek kecakapan berkomunikasi siswa ini diukur berdasarkan instrumen yang dirujuk dari penelitian Rahayu (2013) yang telah diuji reliabilitas dan validitasnya.

Tabel 1.

Aspek Kecakapan Komunikatif Siswa

\begin{tabular}{clccc}
\hline No & \multicolumn{1}{c}{ Aspek yang dinilai } & $\begin{array}{c}\text { Jumlah siswa } \\
\text { yang hadir }\end{array}$ & $\begin{array}{c}\text { Jumlah siswa } \\
\text { yang aktif }\end{array}$ & $\begin{array}{c}\text { Persentase } \\
(\boldsymbol{\%})\end{array}$ \\
\hline 1 & Menyampaikan pertanyaan & 28 & 6 & 21,42 \\
\hline 2 & Menjawab pertanyaan & 28 & 13 & 46,43 \\
\hline 3 & Menyampaikan pendapat & 28 & 11 & 39,29 \\
\hline 4 & Tata bahasa yang baik & 28 & 6 & 21,42 \\
\hline 5 & $\begin{array}{l}\text { Pembicaraan singkat, jelas, dan } \\
\text { mudah dimengerti }\end{array}$ & 28 & 7 & 25,00 \\
\hline 6 & Suaranya terdengar jelas & 28 & 10 & 35,71 \\
\hline 7 & Melihat lawan bicara & 28 & 11 & 39,29 \\
\hline 8 & Ekspresi wajah yang ramah & 28 & 12 & 42,86 \\
\hline 9 & $\begin{array}{l}\text { Gerakan tangan yang sesuai } \\
\text { dengan kata-kata yang diucapkan }\end{array}$ & 28 & 6 & 21,42 \\
\hline \multicolumn{7}{|c}{ Rata-rata pencapaian indikator kecakapan berkomunikasi siswa } \\
\hline
\end{tabular}

Sumber: Lembar observasi, diolah

Tabel 2.

Ketuntasan Hasil Belajar PKn Siswa Pra Siklus Tahun 2017/ 2018

\begin{tabular}{ccccc}
\hline No & Kategori & Jumlah & Persentase & Keterangan \\
\hline 1 & Tuntas & 13 & $46,43 \%$ & Nilai di atas KKM (Nilai $\geq 75)$ \\
\hline 2 & Tidak Tuntas & 15 & $53,57 \%$ & Nilai di bawah KKM (Nilai < 75) \\
\hline & Jumlah & 28 & $100 \%$ & \\
\hline
\end{tabular}

Sumber: Daftar Nilai, diolah

Untuk mengatasi permasalahan di atas oleh peneliti dicobakan Talking Stick berbantuan salindia, yang di dalamnya memuat media pembelajaran berbasis Microsoft PowerPoint untuk mengatasi kejenuhan siswa terhadap buku pegangan yang selama ini dipakai untuk menggali materi. Bahan tayang berbasis Microsoft PowerPoint jauh lebih menarik dari buku pegangan siswa saat sesi menggali materi. Juga memuat model pembelajaran yang mengharuskan siswa pemegang tongkat menjawab pertanyaan guru, diharapkan dapat merangsang, membiasakan, dan melatih kecakapan berkomunikasi siswa. Seiring kecakapan berkomunikasi siswa yang meningkat, hasil belajar juga akan meningkat.

Bertolak dari pembahasan di atas maka rumusan masalah yang dapat diangkat dalam penelitian ini adalah sebagai berikut: (1) bagaimanakah peningkatan kecakapan berkomunikasi siswa setelah Penerapan Talking Stick berbantuan salindia pada pembelajaran PKn kelas 6 SDN Dukuh 03 Salatiga Tahun Pelajaran 2017/2018 materi Politik Luar Negeri Indonesia?, (b) apakah hasil belajar siswa meningkat seiring terjadinya peningkatan kecakapan berkomunikasi setelah Penerapan Talking Stick berbantuan salindia pada pembelajaran PKn kelas 6 SDN Dukuh 03 Salatiga Tahun Pelajaran 2017/2018 materi Politik Luar Negeri Indonesia?

Berdasarkan rumusan masalah di atas maka yang menjadi tujuan dalam penelitian ini adalah: (1) mengetahui seberapa besar peningkatan kecakapan berkomunikasi siswa setelah Penerapan Talking Stick berbantuan salindia pada pembelajaran PKn kelas 6 SDN Dukuh 03 Salatiga Tahun Pelajaran 2017/2018 materi Politik Luar Negeri Indonesia, (2) mengetahui seberapa besar 
peningkatan hasil belajar siswa seiring meningkatnya kecakapan berkomunikasi setelah Penerapan Talking Stick berbantuan salindia pada pembelajaran PKn kelas 6 SDN Dukuh 03 Salatiga Tahun Pelajaran 2017/2018 materi Politik Luar Negeri Indonesia.

\section{KAJIAN PUSTAKA}

Suprijono (2012:109) menyatakan cooperative learning tipe talking stick adalah model pembelajaran yang mendorong siswa berani menyampaikan pendapat. Talking Stick adalah model pembelajaran dengan bantuan tongkat, pemegang tongkat wajib menjawab pertanyaan dari guru setelah mempelajari meteri pokoknya. Tahapan model pembelajaran Talking Stick: (1) talking (berbicara), guru menyajikan materi pelajaran kemudian memberikan kesempatan kepada siswa untuk membaca dan mempelajari materi pada buku pegangannya; (2) stick (tongkat), pada tahap ini guru meminta siswa menutup bukunya kemudian guru mengambil tongkat dan menyerahkan kepada siswa, setelah itu guru mengajukan pertanyaan dan siswa yang memegang tongkat harus menjawabnya, demikian seterusnya sampai sebagian besar siswa mendapat giliran untuk menjawab setiap pertanyaan dari guru; (3) evaluasi, guru merangkum dan membagikan soal tes kepada siswa.

Imas dan Berlin (2016:83) mengatakan tahap-tahap model pembelajaran Talking Stick adalah: (1) guru menyiapkan tongkat, (2) sajian materi pokok, (3) siswa membaca materi lengkap pada wacana, (4) guru mengambil tongkat dan memberikan tongkat kepada siswa dan siswa yang mendapat tongkat menjawab pertanyaan dari guru, (5) tongkat diberikan kepada siswa lain dan guru memberikan pertanyaan lagi dan seterusnya, (6) guru membimbing kesimpulan refleksi-evaluasi. Tujuan utama dari penerapan model pembelajaran Talking Stick ialah mendorong keberanian siswa untuk mengeluarkan pendapat juga untuk mewujudkan kondisi belajar mengajar yang interaktif dan menyenangkan (Huda, 2018: 45). Menurut Norliza, N., \& Noviana, E (2018) Pembelajaran Talking Stick tepat sekali jika diimplementasikan bagi siswa di sekolah dasar. Selain melatih berbicara, pembelajaran ini akan membuat siswa aktif juga menciptakan situasi belajar yang menyenangkan.

Media pemebelajaran memudahkan proses kegiatan belajar mengajar supaya tujuan pembelajaran tercapai ( Hapsari, 2017:4). Dalam Kamus Besar Bahasa Indonesia (KBBI), salindia adalah kata benda yang bermakna terawang fotografi pada pelat kaca tipis yang diatur agar dapat diproyeksikan. Jenis tayangan salindia (slide) yang paling populer dewasa ini adalah tayangan salindia komputer. Sehingga dalam hal ini salindia yang dimaksud adalah media pembelajaran yang berupa tayangan salindia komputer untuk mendukung presentasi.

Komputer merupakan satu di antara sekian banyak media pembelajaran. Penggunaan media pembelajaran dengan memanfaatkan program aplikasi Microsoft PowerPoint dilakukan dengan mengemas materi ajar secara menarik, singkat, padat dan efektif. Microsoft PowerPoint mempunyai fasilitas custom animation yang sangat lengkap (Srimaya , 2017: 54).

Menurut Wirayana (2017:3-4) Microsoft PowerPoint adalah salah satu program komputer untuk presentasi dengan berbagai fitur yang menarik. Pengolahan media PowerPoint dapat dikemas dan dikembangkan sesuai dengan kreatifitas pemakainya sesuai kebutuhan.

Sulman (2017: 125) menyatkan kelebihan pemakaian media TIK slide powerpoint, antara lain: (1) bisa menyampaikan informasi dalam bentuk teks, grafis, audio dan video secara simultan; (2) menyajikan informasi dan pengalaman berharga kepada siswa dari perkembangan software; (3) merangsang motivasi belajar siswa dengan pengalaman baru; (4) kesempatan bagi guru menunjukkan pengalaman baru pada proses pembelajaran; (5) lebih menarik perhatian siswa saat kegiatan belajar mengajar berlangsung; (6) menghemat waktu, pasalnya guru tidak terlalu banyak ceramah, hanya simulasi multimedia saja; (7) mendorong siswa bertanya dan berdiskusi untuk memenuhi keingintahuannya; (8) umumnya bisa menciptakan situasi belajar yang menyenangkan, menarik dan lebih nyata. Berdasar pendapat-pendapat di atas, dapat disimpulkan bahwa salindia presentasi yang dibuat menggunakan Microsoft PowerPoint adalah usaha menyajikan materi secara visual sehingga menarik perhatian siswa dalam menggali materi.

Talking Stick berbantuan salindia adalah pengembangan model pembelajaran cooperative learning tipe Talking Stick yang di dalamnya memuat media pembelajaran berupa salindia (slide) PowerPoint untuk mengatasi kejenuhan siswa terhadap buku pegangan yang selama ini dipakai untuk menggali materi. Model pembelajaran yang mengharuskan siswa pemegang tongkat menjawab pertanyaan guru, diharapkan dapat merangsang, membiasakan, dan melatih kecakapan berkomunikasi 
siswa. Sementara itu, Pambudi (2016) membuktikan penerapan model pembelajaran Talking Stick dapat meningkatkan hasil belajar Matematika siswa di SD Negeri Suryodiningratan II. Penerapan model pembelajaran Talking Stick juga dapat meningkatkan hasil belajar siswa pada kompetensi dasar menjelaskan komunikasi kelas X di SMK Negeri 2 Nganjuk sesuai hasil penelitian Aningrum (2014).

Berikut adalah syntax Salindia dam Talking Stick jika dibandingkan dengan syntax Talking Stick pada umumnya:

Tabel 3.

Perbandingan Syntax Talking Stick dan Talking Stick berbantuan Salindia

\begin{tabular}{|c|c|c|c|}
\hline $\begin{array}{l}\text { Kegiatan } \\
\text { Inti }\end{array}$ & Talking Stick & $\begin{array}{c}\text { Talking Stick } \\
\text { berbantuan Salindia }\end{array}$ & Keterangan \\
\hline & Guru menyiapkan tongkat & & \\
\hline Eksplorasi & $\begin{array}{l}\text { - Guru menyampaikan materi } \\
\text { pokok yang akan dipelajari, } \\
\text { memberikan kesempatan } \\
\text { kepada siswa untuk } \\
\text { mempelajari materi pada } \\
\text { buku paket } \\
\text { - Setelah membaca, siswa } \\
\text { menutup bukunya }\end{array}$ & $\begin{array}{l}\text { - Guru menyampaikan } \\
\text { materi pokok yang akan } \\
\text { dipelajari, memberikan } \\
\text { kesempatan kepada } \\
\text { siswa untuk menyimak } \\
\text { salindia } \\
\text { - Setelah menyimak, } \\
\text { siswa bertanya jawab } \\
\text { dengan teman } \\
\text { sebangku }\end{array}$ & $\begin{array}{l}\text { - Salindia sebagai alternatif } \\
\text { untuk mengatasi } \\
\text { kurangnya media PKn dan } \\
\text { mengatasi kejenuhan siswa } \\
\text { terhadap media yang } \\
\text { monoton } \\
\text { - Tanya jawab dengan } \\
\text { teman untuk memupuk } \\
\text { percaya diri }\end{array}$ \\
\hline Elaborasi & $\begin{array}{l}\text { Guru mengambil tongkat dan } \\
\text { memberikan kepada siswa, } \\
\text { guru memberi pertanyaan dan } \\
\text { siswa yang memegang } \\
\text { tongkat harus menjawabnya. } \\
\text { Demikian seterusnya sampai } \\
\text { sebagian besar siswa } \\
\text { mendapat bagian }\end{array}$ & $\begin{array}{l}\text { Guru mengambil tongkat } \\
\text { dan memberikan kepada } \\
\text { siswa, guru memberi } \\
\text { pertanyaan dan siswa } \\
\text { yang memegang tongkat } \\
\text { harus menjawabnya. } \\
\text { Demikian seterusnya } \\
\text { sampai seluruh siswa } \\
\text { mendapat bagian }\end{array}$ & $\begin{array}{l}\text { Mengaktifkan seluruh siswa, } \\
\text { melatih keberanian dan } \\
\text { keterampilan berkomunikasi } \\
\text { seluruh siswa }\end{array}$ \\
\hline Konfirmasi & $\begin{array}{l}\text { Guru memberikan } \\
\text { kesimpulan }\end{array}$ & $\begin{array}{l}\text { Siswa memberikan } \\
\text { kesimpulan }\end{array}$ & $\begin{array}{l}\text { Student center, guru } \\
\text { bertindak sebagai fasilitator }\end{array}$ \\
\hline
\end{tabular}

Kecakapan Berkomunikasi berarti kecakapan dalam KBBI adalah kemampuan atau kepandaian mengerjakan sesuatu (https://kbbi.kemdikbud.go.id). Salah satu dari empat kecakapan abad 21 yang harus dikuasai siswa adalah kecakapan berkomunikasi. Menurut Davis (2010), komunikasi adalah proses penyampaian pesan dari seseorang kepada orang lain. Sependapat, Hovland (2007), mengatakan komunikasi adalah sebuah proses di mana seseorang (komunikator) menyampaikan pesan (lambang dan atau kata-kata) untuk membentuk tingkah laku orang lain. Dari beberapa pendapat ahli di atas dapat ditarik kesimpulan bahwa komunikasi merupakan proses interaksi antara idividu satu dengan individu lainnya dalam rangka menyampaikan pesan baik langsung maupun tidak langsung di dalam kehidupan sehari-hari.

Berkomunikasi efektif berarti bahwa pengirim pesan dan penerima pesan sama-sama memiliki pengertian yang sama tentang suatu pesan. Johnson, dkk. (2001: 81) menunjukkan cara-cara agar komunikasi efektif dapat dicapai. Menurut mereka, komunikasi efektif dapat terjadi melalui atau dengan didukung oleh aktivitas role-playing, diskusi, aktivitas kelompok kecil dan materi-materi pengajaran yang relevan. Cangara (2011) mengatakan ada dua macam kode dalam berkomunikasi, yaitu: (1) kode verbal, menggunakan bahasa, bahasa merupakan seperangkat kata yang disusun secara terstruktur sehingga menjadi himpunan kalimat yang memiliki arti; (2) kode non verbal, bahasa isyarat, berfungsi meyakinkan sesuatu yang diucapkan, menunjukkan emosi dan perasaan yang tak bisa disampaikan dengan kata-kata, menunjukkan jati diri dan melengkapi atau menambah ucapanucapan yang belum sempurna. Dari beberapa pendapat ahli di atas, dapat ditarik kesimpulan kecakapan berkomunikasi siswa adalah kemampuan siswa untuk mengungkapkan pengetahuan, ide, pemikiran berupa verbal dan non verbal dalam proses pembelajaran.

Hutagalung (2007) mengemukakan beberapa tata cara komunikasi yang efektif, antara lain: (1) melihat lawan bicara, pembicara menatap bola mata ataupun kening lawan bicaranya, sehingga tidak 
terjadinya ketersinggungan, tatapan tidak ke kiri atau ke kanan, pandangan tidak marah atau sinis; (2) suaranya terdengar jelas, harus memperhatikan keras atau tidaknya suara, tidak hanya terdengar samar-samar untuk menghindari ketidakjelasan; (3) ekspresi wajah yang menyenangkan, ekspresi wajah adalah gambaran hati seseorang, sehingga jangan menampilkan ekspresi wajah yang tidak enak; (4) tata bahasa yang baik, penggunaan bahasa sesuai dengan lawan bicaranya; (5) pembicaraan mudah dimengerti, singkat, dan jelas. Pemilihan kosakata yang mudah dimengerti dan kata-kata yang tepat supaya tidak menimbulkan kebingungan lawan bicara.

Nasution (2006:36) menyatakan hasil belajar adalah hasil dari suatu interaksi tindak belajar mengajar dan biasanya ditunjukkan dengan nilai tes yang diberikan guru. Dimyati dan Mudjiono (2002:36) mengatakan hasil belajar adalah hasil yang ditunjukkan dari suatu interaksi tindak belajar dan biasanya ditunjukkan dengan nilai tes yang diberikan guru. Berdasarkan uraian di atas, maka dapat disimpulkan bahwa hasil belajar adalah hasil yang diperoleh siswa setelah terjadinya proses pembelajaran yang ditunjukkan dengan nilai tes dari guru setiap selesai memberikan materi pelajaran.

Memiliki kemampuan berinteraksi dengan bangsa-bangsa lain dalam percaturan dunia secara langsung dengan memanfaatkan teknologi informasi dan komunikasi adalah salah satu tujuan Pendidikan Kewarganegaraan. Untuk mencapai tujuan tersebut siswa perlu belajar. Belajar dapat terjadi dengan proses mengalami. Belajar dengan kegiatan dan pengalaman merupakan penyebab terjadinya perubahan tingkah laku. Di sisi lain, kurangnya ragam media pembelajaran PKn membuat siswa kurang tertarik untuk menggali pengetahuan yang mereka butuhkan. Selain itu model pembelajaran konvensional kurang mampu merangsang kemampuan berkomunikasi siswa. Sehingga tujuan pemerintah mencetak generasi yang tangguh menghadapi persaingan di abad 21 semakin jauh dari harapan. Deskripsi keadaan ini juga terjadi di kelas 6 SDN Dukuh 03 Salatiga. Kecakapan berkomunikasi siswa rendah sehingga hasil belajar yang diperoleh siswa juga belum maksimal. Bahkan lebih banyak siswa mendapat nilai di bawah KKM sehingga tujuan belajar yang diharapkan belum dapat dicapai.

Kenyataan ini menuntut guru untuk lebih kreatif dan inovatif dalam mengemas pembelajaran. Pembelajaran yang menyenangkan dan bermakna tidak lepas dari racikan setiap komponen pembelajaran dengan formula yang tepat. Salindia dalam Talking Stick memiliki kelebihan yaitu mampu memberikan alternatif media yang lebih menarik minat siswa untuk menggali materi. Juga model pembelajaran yang mengharuskan siswa menjawab pertanyaan bisa merangsang kecakapan berkomunikasi siswa. Dengan demikian hasil belajar juga akan meningkat. Berdasarkan latar belakang permasalahan, kerangka teoretis dan kerangka berpikir yang telah diuraikan di atas, maka dapat ditarik kesimpulan sementara (hipotesis) sebagai berikut : (a) diduga Salindia dalam Talking Stick dapat meningkatkan kecakapan berkomunikasi siswa pada mata pelajaran PKn kelas VI SDN Dukuh 03 Salatiga Tahun Pelajaran 2017/2018 materi Politik Luar Negeri Indonesia; (b) diduga peningkatan kecakapan berkomunikasi siswa setelah penerapan Salindia dalam Talking Stick dapat meningkatkan hasil belajar PKn siswa kelas VI SDN Dukuh 03 Salatiga Tahun Pelajaran 2017/2018 materi Politik Luar Negeri Indonesia.

\section{METODE PENELITIAN}

Jenis penelitian yang digunakan dalam penelitian ini adalah penelitian tindakan kelas. Menggunakan model spiral dari Kemmis dan Mc. Teggrat (Wiriaatmadja, 2012: 66) dengan tiga tahapan yaitu (1) perencanaan tindakan (planning), (2) pelaksanaan tindakan (action) dan pengamatan (observation), dan (3) refleksi (reflection). Tiga tahapan tersebut merupakan 1 siklus.

Penelitian ini dilaksanakan di SD Negeri Dukuh 03 Kecamatan Sidomukti Kota Salatiga. Subjek penelitian adalah siswa kelas 6 yang berjumlah 28 siswa, terdiri dari 16 siswa laki-laki, dan 12 siswa perempuan. Rentang usia siswa 12-16 tahun.

Teknik pengambilan data berupa teknik tes dan non tes. Teknik tes diperoleh dari hasil evaluasi siklus 1 dan siklus 2. Teknik non tes diperoleh dari: (1) observasi, mengamati permasalahan maupun keberhasilan yang terjadi selama KBM dengan menggunakan pedoman observasi aktivitas guru dan siswa; (2) dokumentasi pembelajaran yang meliputi aktivitas guru dan siswa serta hal-hal yang terjadi selama kegiatan pembelajaran berlangsung.

Data yang diperoleh akan dianalisis menggunakan deskriptif komperatif yaitu dengan membandingkan data awal dengan data persiklus. Sedangkan untuk data kualitatif dianalisis 
Peningkatan Kecakapan Berkomunikasi dan Hasil Belajar PKn Siswa Kelas 6 dengan Talking Stick Berbantuan Salindia (Hana Septina Kristanti)

menggunakan deskriptif kualitatif berdasarkan hasil observasi dan refleksi dari tiap-tiap siklus. Analisis data kuantitatif berupa hasil belajar per siklus dianalisis yaitu dengan cara menghitung peningkatan ketuntasan belajar siswa secara individu. Dinyatakan tuntas jika siswa memperoleh nilai $\geq 75$, sesuai KKM yang telah ditetapkan di awal tahun pelajaran.

Djamarah (2006:107) mengemukakan untuk mengukur keberhasilan proses pembelajaran dibagi atas beberapa tingkatan taraf sebagai berikut: (1) istimewa, apabila seluruh bahan pelajaran dapat dikuasai siswa; (2) baik sekali, apabila sebagian besar bahan pelajaran dapat dikuasai 76\%-99\%; (3) baik, apabila bahan pelajaran hanya dikuasai $60 \%-75 \%$; (4) kurang, apabila bahan pelajaran yang dikuasai kurang dari $60 \%$.

Berdasarkan uraian di atas, penelitian ini dikatakan berhasil jika nilai rata-rata kecakapan berkomunikasi siswa dan ketuntasan klasikal siswa pada kategori baik (60\%-75\%), sangat baik $(76 \%-99 \%)$, atau istimewa (100\%)

\section{HASIL PENELITIAN DAN PEMBAHASAN}

Hasil kecakapan berkomunikasi siswa pada pra siklus, siklus 1, dan siklus 2.

Tabel berikut ini adalah data rekapituasi perbandingan kecakapan berkomunikasi siswa pra siklus, siklus 1, dan siklus 2 kelas 6 SDN Dukuh 03 Salatiga tahun pelajaran 2017/2018.

Tabel 4.

Perbandingan Kecakapan Berkomunikasi Pra Siklus, Siklus 1, dan Siklus 2

\begin{tabular}{|c|c|c|c|c|c|c|}
\hline \multirow{2}{*}{ No. } & \multirow{2}{*}{ Aspek yang dinilai } & \multirow{2}{*}{$\begin{array}{c}\text { Pra } \\
\text { Siklus }\end{array}$} & \multicolumn{2}{|c|}{ Siklus 1} & \multicolumn{2}{|c|}{ Siklus 2} \\
\hline & & & Pert. 1 & Pert. 2 & Pert. 1 & Pert. 2 \\
\hline 1. & Menyampaikan pertanyaan & 21,42 & 35,71 & 42,86 & 64,29 & 71,43 \\
\hline 2. & Menjawab pertanyaan & 46,43 & 71,43 & 92,86 & 89,29 & 96,43 \\
\hline 3. & Menyampaikan pendapat & 39,29 & 53,57 & 60,71 & 60,71 & 82,14 \\
\hline 4. & Tata bahasa yang baik & 21,42 & 46,43 & 53,57 & 60,71 & 67,86 \\
\hline 5. & Pembicaraan singkat, jelas, dan mudah dimengerti & 25,00 & 53,57 & 64,29 & 64,29 & 71,43 \\
\hline 6. & Suaranya terdengar jelas & 35,71 & 67,86 & 78,57 & 71,43 & 78,57 \\
\hline 7. & Melihat lawan bicara & 39,29 & 64,29 & 71,43 & 85,71 & 89,29 \\
\hline 8. & Ekspresi wajah yang ramah & 42,86 & 78,57 & 85,71 & 89,29 & 96,43 \\
\hline 9. & $\begin{array}{l}\text { Gerakan tangan yang sesuai dengan kata-kata } \\
\text { yang diucapkan }\end{array}$ & 21,42 & 35,71 & 35,71 & 60,71 & 64,29 \\
\hline \multicolumn{2}{|c|}{ Rata-rata } & $32,54 \%$ & $56,34 \%$ & $65,08 \%$ & $71,83 \%$ & $79,76 \%$ \\
\hline
\end{tabular}

Sumber: Lembar Observasi, diolah

Tabel di atas menunjukkan peningkatan kecakapan berkomunikasi siswa. Kecakapan berkomunikasi siswa mengalami peningkatan sebesar 23,8\% dari pra siklus ke siklus 1 pertemuan 1 . Siklus 1 pertemuan 2 meningkat 8,34\% dari siklus 1 pertemuan 1 . Kecakapan berkomunikasi siswa semakin meningkat dari siklus 1 pertemuan 2 ke siklus 2 pertemuan 1 sebesar 6,75\%. Meningkat lagi sebesar 7,93\% dari siklus 2 pertemuan 1 ke siklus 2 pertemuan 2 .

Tabel berikut ini adalah data rekapituasi perbandingan hasil belajar siswa pra siklus, siklus 1 , dan siklus 2 kelas 6 SDN 03 tahun pelajaran 2017/2018.

Tabel 5.

Perbandingan Ketuntasan Hasil Belajar Pra Siklus, Siklus 1, dan Siklus 2

\begin{tabular}{|c|c|c|c|c|c|c|c|c|}
\hline \multirow{2}{*}{ No. } & \multirow{2}{*}{ Kategori } & \multirow[b]{2}{*}{ Nilai } & \multicolumn{2}{|c|}{ Pra Siklus } & \multicolumn{2}{|c|}{ Siklus 1} & \multicolumn{2}{|r|}{ Siklus 2} \\
\hline & & & Jml & Persentase & Jml & Persentase & Jml & Persentase \\
\hline 1 & Tuntas & $\geq 75$ & 13 & $46,43 \%$ & 16 & $57,14 \%$ & 22 & $78,57 \%$ \\
\hline 2 & Tidak Tuntas & $<75$ & 15 & $53,57 \%$ & 12 & $42,86 \%$ & 6 & $21,43 \%$ \\
\hline \multicolumn{3}{|c|}{ Rata-rata } & \multicolumn{2}{|r|}{74,86} & \multicolumn{2}{|r|}{75,36} & \multicolumn{2}{|r|}{83,43} \\
\hline \multicolumn{3}{|c|}{ Nilai Tertinggi } & \multicolumn{2}{|c|}{$\begin{array}{l}88 \text { (1 siswa) } \\
\text { atau } 3,57 \%\end{array}$} & \multicolumn{2}{|c|}{$\begin{array}{c}100 \text { (2 siswa) } \\
\text { atau } 7,14 \%\end{array}$} & \multicolumn{2}{|c|}{$\begin{array}{c}100 \text { ( } 2 \text { siswa) } \\
\text { atau } 7,14 \%\end{array}$} \\
\hline \multicolumn{3}{|c|}{ Nilai Terendah } & \multicolumn{2}{|c|}{$\begin{array}{l}58 \text { (1 siswa) } \\
\text { atau } 3,57 \%\end{array}$} & \multicolumn{2}{|c|}{$\begin{array}{l}40 \text { (1 siwa) } \\
\text { atau } 3,57 \%\end{array}$} & \multicolumn{2}{|c|}{$\begin{array}{c}52(1 \text { siswa }) \\
\text { atau } 3,57 \%\end{array}$} \\
\hline \multicolumn{3}{|c|}{ Ketuntasan Klasikal } & \multicolumn{2}{|c|}{$46,43 \%$} & \multicolumn{2}{|c|}{$57,14 \%$} & \multicolumn{2}{|r|}{$78,57 \%$} \\
\hline
\end{tabular}

Sumber: Daftar Nilai, diolah 
Tabel di atas menunjukkan peningkatan ketuntasan hasil belajar siswa pada dari pra siklus, siklus 1 , dan siklus 2 . Pada pra siklus, hanya 13 siswa $(46,43 \%)$ yang tuntas, sisanya sebanyak 15 siswa $(53,57 \%)$ tidak tuntas. Pada siklus 1 , sebanyak 16 siswa $(57,14 \%)$ tuntas, sedangkan 12 siswa $(42,86 \%)$ tidak tuntas. Setelah dilaksanakan tindakan siklus 2, sebanyak 22 siswa $(78,57 \%)$ tuntas dan sebanyak 6 siswa $(21,43 \%)$ tidak tuntas. Berdasarkan analisis komperatif data kecakapan berkomunikasi siswa serta ketuntasan hasil belajar siswa menunjukkan adanya peningkatan, begitu pula bila disejajarkan dengan indikator keberhasilan maka tindakan siklus 2 dinyatakan sudah berhasil.

Menilik penelitian-penelitian terdahulu yang telah membuktikan kemangkusan media presentasi PowerPoint (Salinda) untuk meningkatkan keterampilan berkomunikasi (Rahayu, 2013). Keberhasilan penerapan model pembelajaran Talking Stick untuk meningkatkan hasil belajar siswa (Pambudi, 2016). Juga keberhasilan penelitian (Ainingrum, 2014) yang menyatakan model pembelajaran Talking Stick dapat meningkatkan hasil belajar siswa pada kompotensi dasar menjelaskan komunikasi. Maka keberhasilan penerapan Salindia dalam Talking Stick untuk meningkatkan kecakapan berkomunikasi dan hasil belajar siswa dapat dijadikan salah satu alternatif solusi bagi rekan sejawat yang mengalami permasalahan serupa.

\section{SIMPULAN DAN SARAN}

Berdasarkan hasil penelitian terhadap kecakapan berkomunikasi dan hasil belajar siswa pada pembelajaran PKn dengan penerapan salindia dalam talking stick, dapat disimpulkan bahwa: (1) kecakapan berkomunikasi siswa mengalami peningkatan. Hal ini terbukti dari hasil observasi kecakapan berkomunikasi siswa pada tiap siklus. Kecakapan berkomunikasi siswa mengalami peningkatan sebesar $23,8 \%$ dari pra siklus ke siklus 1 pertemuan 1 . Siklus 1 pertemuan 2 meningkat $8,34 \%$ dari siklus 1 pertemuan 1 . Kecakapan berkomunikasi siswa semakin meningkat dari siklus 1 pertemuan 2 ke siklus 2 pertemuan 1 sebesar 6,75\%. Meningkat lagi sebesar 7,93\% dari siklus 2 pertemuan 1 ke siklus 2 pertemuan 2; (2) peningkatan kecakapan berkomunikasi siswa terbukti dapat meningkatkan hasil belajar siswa dalam pembelajaran PKn materi Politik Luar Negeri Indonesia. Hal ini dapat dibuktikan dari peningkatan ketuntasan hasil belajar siswa. Pada pra siklus, hanya 13 siswa $(46,43 \%)$ yang tuntas, sisanya sebanyak 15 siswa $(53,57 \%)$ tidak tuntas. Pada siklus 1 , sebanyak 16 siswa $(57,14 \%)$ tuntas, sedangkan 12 siswa $(42,86 \%)$ tidak tuntas. Setelah dilaksanakan tindakan siklus 2, sebanyak 22 siswa $(78,57 \%)$ tuntas dan sebanyak 6 siswa $(21,43 \%)$ tidak tuntas.

Berdasarkan hasil penelitian yang telah dilakukan, ada beberapa saran yang dapat penulis sampaikan sebagai berikut: Bagi guru sebagai peneliti : Salindia yang menarik dapat membuat siswa fokus dalam sesi menggali materi, engedarkan tongkat dengan diiringi lagu penting untuk mencairkan suasana, Bagi siswa : Keberanian bertanya, menjawab, dan berpendapat perlu terus dipupuk sehingga kecakapan berkomunikasi sebagai bekal masa depan di era global dapat terus dilatih dan meningkat, kecakapan berkomunikasi mutlak diperlukan untuk memenangkan persaingan di era global, Bagi sekolah : sebagai bahan acuan untuk kelas yang mengalami permasalahan serupa, sehingga kualitas pembelajaran semakin baik.

\section{UCAPAN TERIMAKASIH}

Terima kasih peneliti ucapkan kepada Universitas Kristen Satya Wacana, khususnya FKIPPGSD dengan program pengabdian masyarakatnya yang bekerja sama dengan Gugus Joko Tingkir Kecamatan Tingkir Kota Salatiga. Lewat program tersebut, peneliti dibimbing selama pelaksanaan hingga penyelesaian laporan penelitian ini. Tidak berhenti di situ, pembimbingan berlanjut hingga penelitian ini siap dijurnalkan dalam bentuk artikel. Juga kepada Kepala SDN Dukuh 03 Salatiga yang telah mengijinkan peneliti untuk melaksanakan penelitian. Teman sejawat yang bersedia menjadi observer juga keluarga yang selalu mendukung penulis dalam menyelesaikan penelitian ini. 
Peningkatan Kecakapan Berkomunikasi dan Hasil Belajar PKn Siswa Kelas 6 dengan Talking Stick

Berbantuan Salindia (Hana Septina Kristanti)

\section{DAFTAR PUSTAKA}

Aningrum, Aprilia Ayu. 2014. Penerapan Model Pembelajaran Talking Stick untuk Meningkatkan Hasil Belajar Siswa pada Kompetensi Dasar Menjelaskan Komunikasi Kelas X APK1 di SMK Negeri 2 Nganjuk, dalam e-Journal UNESA Vol 2, No 2 (2014). Hal 7- 8

Cangara, Hafied. 2011. Pengantar Ilmu Komunikasi. Jakarta: PT. Raja Grafindo Persada.

Davis, Keith. 2010. Organizational Behavior-Human Behavior at Work 13th Edition. New Delhi: Mcgraw Hill Company.

Davis, Keith. 2010. Organizational Behavior-Human Behavior at Work 13th Edition. New Delhi: Mcgraw Hill Company.

Dimyati, \& Mudjiono. 2002. Belajar dan Pembelajaran. Jakarta: Rineka Cipta.

Djamarah, S.B. 2006. Strategi Belajar Mengajar. Jakarta: Rineka Cipta.

Hapsari, A.E. (2017). Penerapan Model Pembelajaran Kooperatif Tipe Numbered Heads Together Berbantuan Media Interaktif untuk Meningkatkan Aktifitas dan Prestasi Belajar Siswa. Scholaria:Jurnal Pendidikan dan Kebudayaan, 7(1), Hal 4

Huda, F. 2018. Penerapan Model Pembelajaran Talking Stick dalam Upaya Peningkatan Hasil Belajar Pokok Bahasan Pancasila Sebagai Dasar Negara Republik Indonesia Kelas VI Tahun Pelajaran 2017/2018, dalam Jurnal PTK dan Pendidikan, 3(2), 45 - 53

Hovland, Carl L. 2007. Definisi Komunikasi. Jakarta: PT. Raja Grafindo Persada.

Hutagalung, Inge. 2007. (Pengembangan Kepribadian (Tinjauan Praktis Menuju Pribadi Positif). Jakarta: PT. Macanan Jaya Cemerlang.

Imas \& Berlin.2016. Ragam Pengembangan Model Pembelajaran Untuk Meningkatkan Profesionalitas Guru. Jakarta: Kata Pena.

Johnson, Daniel; Peter Sutton dan Neil Harris. 2001. "Extreme Programming Requires Extreemely Effective Communication Skills to Students in an IT Degree."http://www.ascilite.org.au/conferences/melbourne01/pdf//papers/johnsond.pdf (diakses tanggal 11 Maret 2018).

Kemdikbud. 2017. Panduan Implementasi Kecakapan Abad 21 Kurikulum 2013 di Sekolah Menengah Atas. Jakarta: Kemdikbud.

Nasution, S. 2006. Berbagi Pendekatan Dalam Proses Belajar Mengajar. Jakarta: Rineka Cipta.

Norliza, N., \& Noviana, E. 2018. Penerapan Model Pembelajaran Kooperative Tipe Talking Stick untuk meningkatkan Hasil Belajar IPS Siswa Kelas IV SDN 49 Tameran Kecamatan Bengkalis, dalam Jurnal Online Mahasiswa (JOM) Bidang Keguruan dan Ilmu Pendidikan, $4(1), 1-13$.

Pambudi, Rendi Lilit Iman. 2016. Penerapan Model Pembelajaran Talking Stick Untuk Meningkatkan Hasil Belajar Matematika Pada Siswa Kelas IV SD N Suryodiningratan II Tahun Ajaran 2015/2016.

Rahayu, Esti Lila. 2013. Penggunaan Media Presentasi Power Point Untuk Meningkatkan Keterampilan Berkomunikasi Belajar IPS Pada Siswa Kelas VII A SMP Negeri 4 Kalasan Tahun Ajaran 2012/2013.

Srimaya, S. 2017. Efektivitas Media Pembelajaran PowerPoint Untuk Meningkatkan Motivasi dan Hasil Belajar Biologi Siswa, dalam Jurnal Biotek, 5(1), 53-68.

Sulman, S., Adlim, A., \& Ilyas, S. (2017). Peningkatan Motivasi Dan Hasil Belajar Siswa SMP Pada Materi Getaran Dan Gelombang Dengan Menggunakan Media Tik Slide Powerpoint Dan Demonstrasi Alat Sederhana (Penelitian Di SMP Negeri 2 Meurah Mulia Kabupaten Aceh Utara), dalam Jurnal Pendidikan Sains Indonesia, 3(2), 122-130. 
Scholaria: Jurnal Pendidikan dan Kebudayaan, Vol. 8 No. 3, September 2018: 293-301

Suprijono, Agus. 2012. Cooperative Learning (Teori dan Aplikasi PAIKEM). Yogyakarta: Pustaka Pelajar.

Wiriaatmadja, Rochiati. 2012. Metode Penelitian Tindakan Kelas. Bandung: PT. Remaja Rosdakarya https://kbbi.kemdikbud.go.id diakses 6 Maret 2018. 